\title{
The Impact of Repeated $\mathrm{Hb} \mathrm{A}_{2}$ Measurements on $\beta$-Thalassemia Trait Diagnosis
}

\section{Al-Jafar $\mathrm{H}^{*}$, Bahzad S ${ }^{2}$, Al-Awadhi $\mathrm{AM}^{3}$, Al Nahham $\mathrm{M}^{1}$, Pagaa MR ${ }^{1}$, Bourusly $\mathrm{MJ}^{4}$ and AlSayiegh $\mathrm{H}^{5}$}

${ }^{1}$ Department of Haematology, Amiri Hospital, Kuwait

${ }^{2}$ Clinical and Molecular Genetics, Kuwait Medical Genetics Center and Kuwait Cancer Control Centre, Kuwait

${ }^{3}$ Medical laboratory Sciences, Faculty of Allied Health Sciences, Kuwait University, Kuwait

${ }^{4}$ Clinical Paediatric Haematologist, NBK Paediatric Hospital, Kuwait

${ }^{5}$ Kuwait Association for Biomedical Engineers, Kuwait

${ }^{*}$ Corresponding author: Al-Jafar H, Consultant Haematologist, Department of Haematology, Amiri Hospital, Kuwait, E-mail: cbc9@hotmail.com

Citation: Al-Jafar H, Bahzad S, Al-Awadhi AM, Al Nahham M, Pagaa MR, et al. (2016) The Impact of Repeated $\mathrm{Hb} \mathrm{A}_{2}$ Measurements on $\beta$-Thalassemia Trait Diagnosis. J Hematol Blood Disord 2(2): 204. doi: 10.15744/2455-7641.2.204

Received Date: June 17, 2016 Accepted Date: July 19, 2016 Published Date: July 21, 2016

\begin{abstract}
Introduction: Hemoglobin $\mathrm{A}_{2}\left(\mathrm{Hb} \mathrm{A}_{2}\right)$ is a minor component of the hemoglobin present in normal adult red blood cells, accounting for $1.5-3.5 \%$ of the total hemoglobin in healthy individuals. The $\mathrm{Hb} \mathrm{A}_{2}$ level is the most significant parameter to identify $\beta$-thalassemia carriers. We aimed to study the effect of repeated measurements of $\mathrm{Hb} \mathrm{A}_{2}$ levels on $\beta$-thalassemia trait diagnosis.

Methods: Repeated HPLC tests were conducted for 107 patient samples. Results were categorized into variant interval ranges (VIRs); each interval has $0.25 \%$ deviation from the repeated test. The following six VIRs were created: $0.25,0.50,0.75,1.00,1.25$, and $1.50 \%$. HPLC results were interpreted in correlation with red blood cell indices, and serum ferritin. Serum ferritin was available for 76 patients from medical records.

Results: All samples showed different degrees of variation between repeated test results. The variations ranged from $0.25 \%$ VIR in 51 (47\%) of the repeated test results and $1.5 \%$ VIR in 7 (7\%).

Conclusion: The normal range $\mathrm{Hb} \mathrm{A}_{2}$ levels are very narrow window. Repeated HPLC results for samples showed degrees of variation that could alter $\beta$-thalassemia trait diagnosis. Alert technical work and careful clinical interpretation are mandatory to avoid wrong diagnosis related to $\mathrm{Hb} \mathrm{A}$ level in $\beta$-thalassemia trait and other related hemoglobin disorders. This comparative study on repeated HPLC for $\mathrm{Hb} \mathrm{A}_{2}$ levels has great importance to avoid either false negative or false positive results.
\end{abstract}

Keywords: Hemoglobinopathy; Standardization; HPLC; Thalassemia minor; Quality control

\section{Introduction}

Hemoglobin $\mathrm{A}_{2}\left(\mathrm{Hb} \mathrm{A}_{2}\right)$ level is the most significant parameter in the identification of $\beta$-thalassemia carriers. A small percentage of hemoglobin $\mathrm{A}_{2}$ is present in normal adult red blood cells (RBC), accounting for about 1.5-3.5\% of the total Hb in healthy individuals [1]. Several research studies have confirmed typical increase of $\mathrm{Hb} \mathrm{A}_{2}$ in $\beta$ thalassemia carriers, thus providing evidence for the use of $\mathrm{Hb} \mathrm{A}_{2}$ as a diagnostic tool for such condition [2]. From that time on, $\beta$ thalassemia carriers have been diagnosed by their $\mathrm{Hb} \mathrm{A}_{2}$ levels, which are usually above normal average. Other evidence, collected through the United Kingdom National External Quality Assessment Service (NEQAS) survey showed that some High Performance Liquid Chromatography (HPLC) methods are not well aligned with those of other systems, with a positive bias of up to $0.5 \%$ in $\mathrm{Hb} \mathrm{A}_{2}$ results [3]. Iron deficiency could interfere with the diagnosis of $\beta$-thalassemia trait [4]. In patients with the $\beta$-thalassemia trait, iron level could be elevated and iron-depleted $\beta$-thalassemia carriers are found to have no significant reduction in $\mathrm{Hb} \mathrm{A}_{2}$ level, although other studies reported low $\mathrm{Hb} \mathrm{A}_{2}$ in iron deficiency anemia $[5,6]$. Moreover, reduced $\mathrm{Hb} \mathrm{A}_{2}$ levels can be detected in the presence of $\alpha$-thalassemia mutations, probably due to preferential binding of the $\alpha$-chains with the $\beta$ rather than with their $\delta$ counterparts. This is clearly seen in hemoglobin $H$ disease $(\mathrm{Hb} \mathrm{H})$, where $\mathrm{Hb} \mathrm{A}_{2}$ can drop to less than 1\% [7]. Hb $\mathrm{A}_{2}$ levels could also be affected by congenital or acquired factors (Figure 1). The $\mathrm{Hb} \mathrm{A}_{2}$ variations detected by repeated HPLC tests in this study could potentially influence the diagnosis of the $\beta$-thalassemia trait and another hemoglobinopathies. Therefore, this study highlights the impact of such variations on $\mathrm{Hb} \mathrm{A}_{2}$ level quality control determined by HPLC testing. 


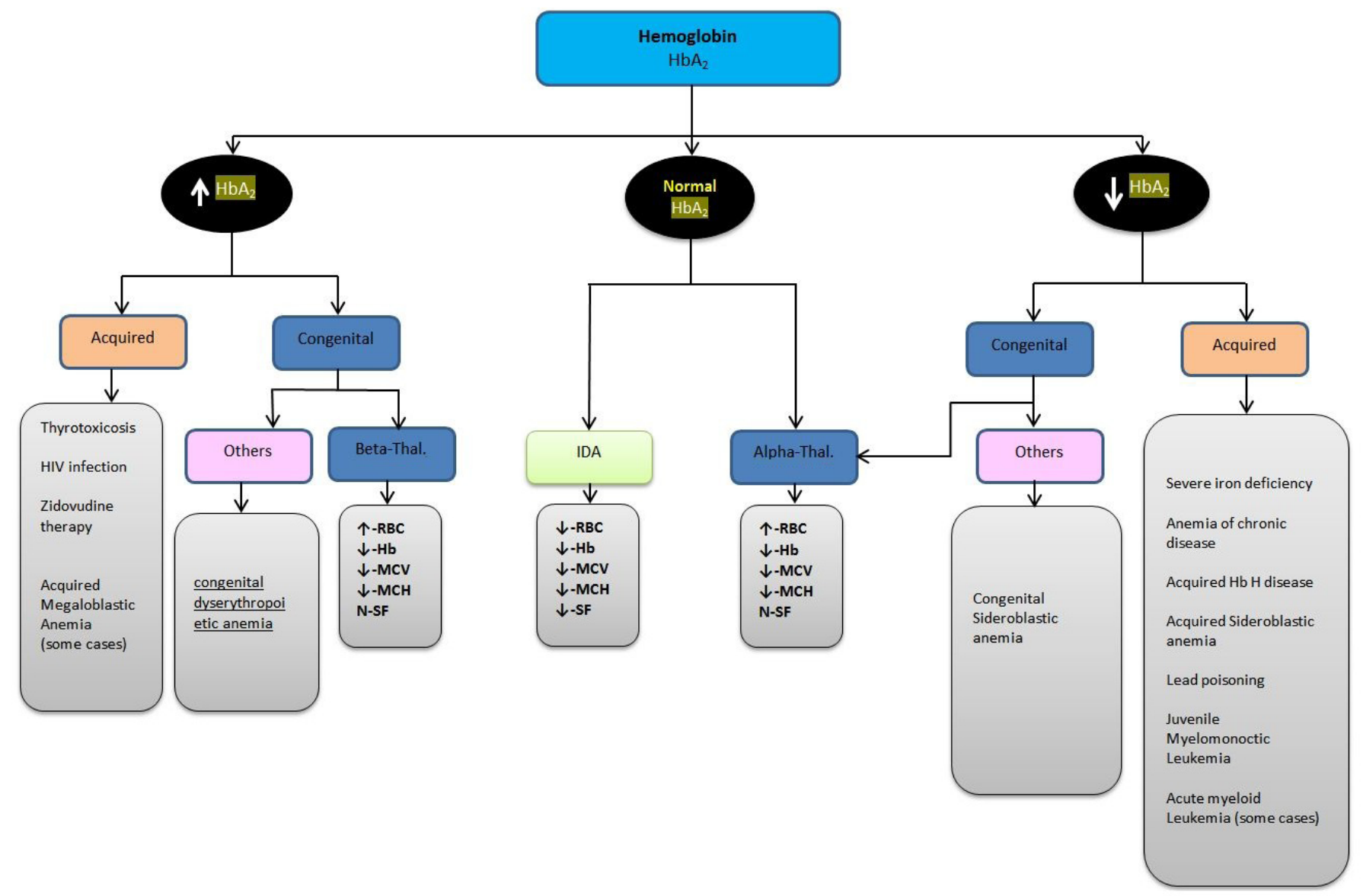

$\beta$-Thal $=\beta$-Thalassemia $\alpha$-Thal $=\alpha$ Thalassemia IDA $=$ Iron deficiency anemia RBC $=$ Red blood count; Hb = Hemoglobin; $\mathrm{MCV}=\mathrm{Mean}$ corpuscular volume; $\mathrm{MCH}=$ Mean corpuscular Hemoglobin; SF = Serum ferritin; $\mathrm{n}=$ normal

Figure 1: Causes of different $\mathrm{HbA}_{2}$ levels with the hematology laboratory results comparison between $\beta$-Thal, $\alpha$-Thal, IDA

\section{Method}

A retrospective study was conducted to assess the variation between repeated HPLC results for the same sample. In our medical records, 107 patients were found to have repeated HPLC tests between 2010 and 2015 without known the reasons why the test was repeated, most likely it were repeated without checking the availability of the results in the records. HPLC analysis was performed using the Waters Corporation machine model 2487 Dual $\lambda$ Absorbance Detector. From available records, samples that were repeat tested by HPLC and had high Hb A levels were included in this study. Samples with another hemoglobinopathy such as S, D, G, E, thalassemia major, or thalassemia intermedia were excluded. HPLC results were interpreted in correlation with red blood cell indices and serum ferritin levels. All the tested samples performed on same machine throughout this period. Each sample was repeated only one time but not on the same day. The variation interval ranges were vary between few days and several months. Serum ferritin was available in our data for 76 patients but it was not done at the same time as HPLC. It was included to give a useful available relevant data.

\section{Results}

Repeated HPLC measurements revealed variations in $\mathrm{Hb} \mathrm{A}_{2}$ levels (Table 1). These variations were categorised into variation interval ranges (VIRs); each VIR spanned 0.25\%. Six VIRs were created 0.25, 0.50, 0.75, 1.00, 1.25, and 1.50\%. Variations were detected in all the 107 samples had repeated HPLC tests. Analysis of the results of the 107 repeat tested samples revealed that 51 (47\%) samples were in the $0.25 \%$ VIR; 28 (26\%) samples were in the $0.5 \%$ VIR; 14 (13\%) samples were in the 0.75\% VIR; 5 (5\%) samples were in the $1.00 \%$ VIR; 2 (2\%) samples were in the 1.25\% VIR; and 7 (7\%) samples were in the 1.5\% VIR. Serum ferritin level were available for 76 patients. Of these, 63 patients had normal serum ferritin levels; 2 patients had high serum ferritin; and 11 patients had low serum ferritin. After repeated testing, $\mathrm{Hb} \mathrm{A}_{2}$ were corrected from normal level to high level for 2 samples according to high $\mathrm{RBC}$, high $\mathrm{Hb}$, low MCV and low MCH from normal level to high level for 2 samples (Table 2). The Hb $\mathrm{A}_{2} \mathrm{VIRs}$ for all 107 samples were correlated to their RBC indices, Hb levels, and serum ferritin levels according to the hematology reference values based on age and gender (Table 3 ). 


\begin{tabular}{|c|c|c|c|c|c|c|c|c|c|}
\hline $\begin{array}{c}\mathrm{HbA}_{2} \\
\text { Variations } \\
\text { intervals }\end{array}$ & Count & percentage & $\begin{array}{c}\text { Hb A } \\
\text { Mean } \pm \text { SD } \\
(96-98)\end{array}$ & $\begin{array}{c}\mathrm{HbA}_{2} \\
\text { Mean } \pm \text { SD } \\
(1.5-3.5)\end{array}$ & $\begin{array}{c}\text { Hb F } \\
\text { Mean } \pm \text { SD } \\
<1\end{array}$ & $\begin{array}{c}\text { RBC } \\
(4.5-5.5) \\
10^{12} / \mathrm{L}\end{array}$ & $\begin{array}{c}\mathrm{Hb} \\
(130-170) \\
\mathrm{g} / \mathrm{L}\end{array}$ & $\begin{array}{c}\text { MCV } \\
(83-101) \\
\text { fL }\end{array}$ & $\begin{array}{c}\text { MCH } \\
(27-32) \\
\text { pg }\end{array}$ \\
\hline 0.25 & 51 & $47 \%$ & $92.86 \pm 2.56$ & $5.19 \pm 0.67$ & $3.30 \pm 2.46$ & $5.62 \pm 0.59$ & $110 \pm 12.2$ & $62.2 \pm 4.00$ & $19.6 \pm 1.41$ \\
\hline 0.50 & 28 & $26 \%$ & $93.52 \pm 2.48$ & $5.12 \pm 0.75$ & $2.52 \pm 3.00$ & $5.59 \pm 0.83$ & $107 \pm 13.1$ & $60.9 \pm 4.47$ & $19.3 \pm 1.66$ \\
\hline 0.75 & 14 & $13 \%$ & $93.24 \pm 2.53$ & $5.29 \pm 0.62$ & $2.58 \pm 2.82$ & $5.43 \pm 0.90$ & $106 \pm 16.7$ & $62.8 \pm 4.04$ & $19.6 \pm 1.45$ \\
\hline 1.00 & 5 & $5 \%$ & $92.70 \pm 3.49$ & $5.11 \pm 0.62$ & $3.63 \pm 3.73$ & $5.29 \pm 0.83$ & $104 \pm 12.5$ & $63.6 \pm 5.06$ & $19.8 \pm 1.72$ \\
\hline 1.25 & 2 & $2 \%$ & $90.54 \pm 2.67$ & $5.43 \pm 0.54$ & $5.38 \pm 2.37$ & $5.47 \pm 0.43$ & $100 \pm 3.77$ & $56.3 \pm 2.28$ & $18.5 \pm 1.12$ \\
\hline 1.50 & 7 & $7 \%$ & $94.31 \pm 2.13$ & $4.53 \pm 1.11$ & $2.41 \pm 1.58$ & $5.14 \pm 0.83$ & $106 \pm 15.7$ & $64.8 \pm 5.41$ & $20.7 \pm 1.85$ \\
\hline
\end{tabular}

Table 1: $\mathrm{Hb} \mathrm{A}_{2}$ variation intervals range

\begin{tabular}{|c|c|c|c|c|c|c|c|c|c|c|c|}
\hline No & Gender & $\begin{array}{c}\mathrm{HbA}_{2} \\
\text { variations }\end{array}$ & Repeated & $\begin{array}{c}\text { Hb A } \\
(96-98 \%)\end{array}$ & $\begin{array}{c}\text { HbA }_{2} \\
(1.5-3.5 \%)\end{array}$ & $\begin{array}{l}\mathrm{Hb} \mathrm{F} \\
<1 \%\end{array}$ & $\begin{array}{c}\mathrm{RBC} \\
(4.5-5.5) \\
10^{12} / \mathrm{L} \\
\end{array}$ & $\begin{array}{c}\text { Hb } \\
(130-170) \\
\mathrm{g} / \mathrm{L}\end{array}$ & $\begin{array}{c}\text { MCV } \\
(83-101) \\
\mathrm{fL} \\
\end{array}$ & $\begin{array}{c}\text { MCH } \\
(27-32) \\
\text { pg }\end{array}$ & $\begin{array}{c}\text { Ferritin } \\
(23-336) \\
\text { ng/mL }\end{array}$ \\
\hline \multirow{2}{*}{1} & \multirow{2}{*}{ M } & \multirow{2}{*}{2.64} & $1^{\mathrm{st}}$ & 97.07 & 2.7 & $<1$ & 5.32 & 102 & 60 & 19 & 16.3 \\
\hline & & & $2^{\text {nd }}$ & 94.10 & 5.4 & $<1$ & 5.29 & 99 & 58 & 19 & 37.6 \\
\hline \multirow{2}{*}{2} & \multirow{2}{*}{ M } & \multirow{2}{*}{2.27} & $1^{\text {st }}$ & 98.00 & 2.4 & - & 5.74 & 125 & 68 & 22 & 84.9 \\
\hline & & & $2^{\text {nd }}$ & 90.73 & 4.7 & 4.60 & 4.99 & 105 & 66 & 21 & \\
\hline
\end{tabular}

Table 2: $\mathrm{Hb} \mathrm{A}_{2}$ level before and after repetition in correlation to $\mathrm{RBC}$ indices and serum ferritin level

\begin{tabular}{|c|c|c|c|c|c|c|c|c|c|c|c|}
\hline $\begin{array}{c}\mathrm{HbA}_{2} \\
\mathrm{AIR}\end{array}$ & Gender & Age & $\mathbf{N}$ & $\begin{array}{c}\text { Hb A } \\
(96-98)\end{array}$ & $\begin{array}{l}\mathrm{HbA}_{2} \\
(1.5-3.5)\end{array}$ & $\begin{array}{c}\mathrm{Hb} \mathrm{F} \\
<1\end{array}$ & $\begin{array}{c}\mathrm{RBC} \\
(4.5-5.5) \\
10^{12} / \mathrm{L}\end{array}$ & $\begin{array}{c}\mathrm{Hb} \\
(130-170) \\
\mathrm{g} / \mathrm{L}\end{array}$ & $\begin{array}{c}\text { MCV } \\
(83-101) \\
\text { fL }\end{array}$ & $\begin{array}{c}\text { MCH } \\
(27-32) \\
\text { pg }\end{array}$ & $\begin{array}{c}\text { Ferritin } \\
(23-336) \\
\mathrm{ng} / \mathrm{mL}\end{array}$ \\
\hline 0.25 & \multirow{2}{*}{$\mathrm{F}$} & $1-16$ & 11 & $91.86 \pm 2.65$ & $5.17 \pm 0.49$ & $3.87 \pm 2.63$ & $5.59 \pm 0.50$ & $106 \pm 10.0$ & $60.5 \pm 2.52$ & $19.0 \pm 1.00$ & $22 \pm 16$ \\
\hline 0.25 & & $18-82$ & 17 & $93.08 \pm 2.29$ & $5.26 \pm 0.76$ & $2.77 \pm 1.68$ & $5.33 \pm 0.50$ & $107 \pm 10.0$ & $63.6 \pm 4.38$ & $20.2 \pm 1.29$ & $29 \pm 23$ \\
\hline 0.25 & \multirow{2}{*}{ M } & $1-16$ & 9 & $91.31 \pm 2.88$ & $5.54 \pm 0.55$ & $4.33 \pm 3.42$ & $5.78 \pm 0.39$ & $106 \pm 9.0$ & $59.2 \pm 2.35$ & $18.3 \pm 1.02$ & $44 \pm 24$ \\
\hline 0.25 & & $19-77$ & 14 & $94.06 \pm 2.14$ & $4.87 \pm 0.57$ & $3.33 \pm 2.75$ & $5.96 \pm 0.67$ & $120 \pm 14.0$ & $63.7 \pm 3.59$ & $20.2 \pm 1.23$ & $129 \pm 145$ \\
\hline 0.50 & \multirow{2}{*}{$\mathrm{F}$} & $3-14$ & 8 & $92.23 \pm 2.53$ & $5.54 \pm 0.86$ & $3.13 \pm 2.66$ & $5.69 \pm 0.58$ & $104 \pm 9.5$ & $58.5 \pm 2.16$ & $18.3 \pm 1.00$ & $48 \pm 46$ \\
\hline 0.50 & & $18-69$ & 12 & $94.59 \pm 1.07$ & $4.79 \pm 0.50$ & $1.26 \pm 1.00$ & $5.26 \pm 0.70$ & $105 \pm 13.0$ & $63.2 \pm 5.12$ & $20.2 \pm 1.93$ & $122 \pm 236$ \\
\hline 0.50 & \multirow{2}{*}{ M } & $1-15$ & 6 & $93.15 \pm 3.34$ & $5.23 \pm 0.69$ & $3.70 \pm 4.94$ & $5.85 \pm 1.14$ & $111 \pm 15.5$ & $60.4 \pm 4.32$ & $19.2 \pm 1.33$ & $43 \pm 4$ \\
\hline 0.50 & & 63 & 2 & $94.69 \pm 0.65$ & $4.62 \pm 0.17$ & $1.06 \pm 0.60$ & $6.11 \pm 0.34$ & $117 \pm 8.3$ & $62.5 \pm 1.12$ & $19.2 \pm 0.43$ & $103 \pm 53$ \\
\hline 0.75 & \multirow{2}{*}{$\mathrm{F}$} & $13-16$ & 3 & $94.21 \pm 0.59$ & $5.28 \pm 0.56$ & $0.69 \pm 0.28$ & $5.56 \pm 0.89$ & $106 \pm 19.7$ & $60.6 \pm 3.77$ & $19.0 \pm 1.41$ & $16 \pm 12$ \\
\hline 0.75 & & $22-45$ & 6 & $92.39 \pm 3.26$ & $5.39 \pm 0.49$ & $4.41 \pm 3.74$ & $4.75 \pm 0.55$ & $98 \pm 12.5$ & $66.0 \pm 3.44$ & $20.6 \pm 1.44$ & $769 \pm 893$ \\
\hline 0.75 & \multirow{2}{*}{ M } & $4-14$ & 3 & $92.26 \pm 2.25$ & $5.51 \pm 0.73$ & $3.25 \pm 0.67$ & $5.90 \pm 0.34$ & $111 \pm 7.1$ & $60.2 \pm 2.27$ & $19.0 \pm 1.0$ & 31 \\
\hline 0.75 & & $39-58$ & 2 & $94.90 \pm 0.74$ & $4.81 \pm 0.59$ & $0.46 \pm 0.09$ & $6.33 \pm 0.80$ & $121 \pm 15.3$ & $62.0 \pm 1.67$ & $19.2 \pm 1.0$ & $99 \pm 23$ \\
\hline 1.00 & \multirow{2}{*}{$\mathrm{F}$} & $10-16$ & 2 & $93.81 \pm 1.73$ & $5.20 \pm 0.59$ & $3.87 \pm 0.00$ & $5.62 \pm 0.20$ & $105 \pm 2.9$ & $60.5 \pm 1.12$ & $18.7 \pm 0.43$ & 12 \\
\hline 1.00 & & $22-30$ & 2 & $94.54 \pm 1.07$ & $5.07 \pm 0.70$ & $0.52 \pm 0.37$ & $4.65 \pm 0.99$ & $101 \pm 19.3$ & $69.2 \pm 2.86$ & $21.7 \pm 0.83$ & $458 \pm 317$ \\
\hline 1.00 & M & 1 & 1 & $86.83 \pm 2.97$ & $5.00 \pm 0.44$ & $8.18 \pm 2.53$ & $5.91 \pm 0.15$ & $106 \pm 2.0$ & $58.5 \pm 0.50$ & $18.0 \pm 0.00$ & 13 \\
\hline 1.25 & M & $1-6$ & 2 & $90.54 \pm 2.67$ & $5.43 \pm 0.54$ & $5.38 \pm 2.37$ & $5.47 \pm 0.43$ & $100 \pm 3.77$ & $56.2 \pm 2.28$ & $18.5 \pm 1.12$ & $32 \pm 3.3$ \\
\hline 1.50 & $\mathrm{~F}$ & $23-56$ & 3 & $94.54 \pm 1.67$ & $4.58 \pm 1.08$ & $2.16 \pm 1.50$ & $4.57 \pm 0.70$ & $95 \pm 11.0$ & $66.0 \pm 6.0$ & $21.0 \pm 2.00$ & $235 \pm 24$ \\
\hline 1.50 & \multirow{2}{*}{ M } & 1 & 1 & $95.59 \pm 1.49$ & $4.06 \pm 1.32$ & $<1$ & $5.31 \pm 0.02$ & $101 \pm 1.50$ & $59.0 \pm 1.0$ & $19.0 \pm 0.00$ & 38 \\
\hline 1.50 & & $49-57$ & 3 & $93.63 \pm 2.54$ & $4.59 \pm 1.05$ & $2.56 \pm 1.60$ & $5.82 \pm 0.50$ & $121 \pm 11.0$ & $65.0 \pm 4.0$ & $21.0 \pm 2.00$ & $100 \pm 15$ \\
\hline
\end{tabular}

Table 3: $\mathrm{Hb} \mathrm{A}_{2}$ variations in correlation with $\mathrm{RBC}$ indices, hemoglobin and serum ferritin according to hematology reference values in different age and gender

\section{Discussion}

An elevated $\mathrm{Hb} \mathrm{A_{2 }}$ determined by the HPLC test, normal or high serum ferritin, microcytic hypochromic features, high RBC count, and low to normal total hemoglobin, are parameters to determine $\beta$-thalassemia trait diagnosis. $\mathrm{Hb} \mathrm{A}_{2}$ plays an integral role in identifying the carrier status of a subject. The range for considering $\mathrm{Hb} \mathrm{A}_{2}$ levels as normal is very narrow; therefore, a slight 
increase or decrease in the $\mathrm{Hb} \mathrm{A}_{2}$ level could change the diagnosis from being considered positive for the $\beta$-thalassemia trait to normal and vice versa. The repeated HPLC tests show variation differences according to VIRs which could change the diagnosis (Figure 2).

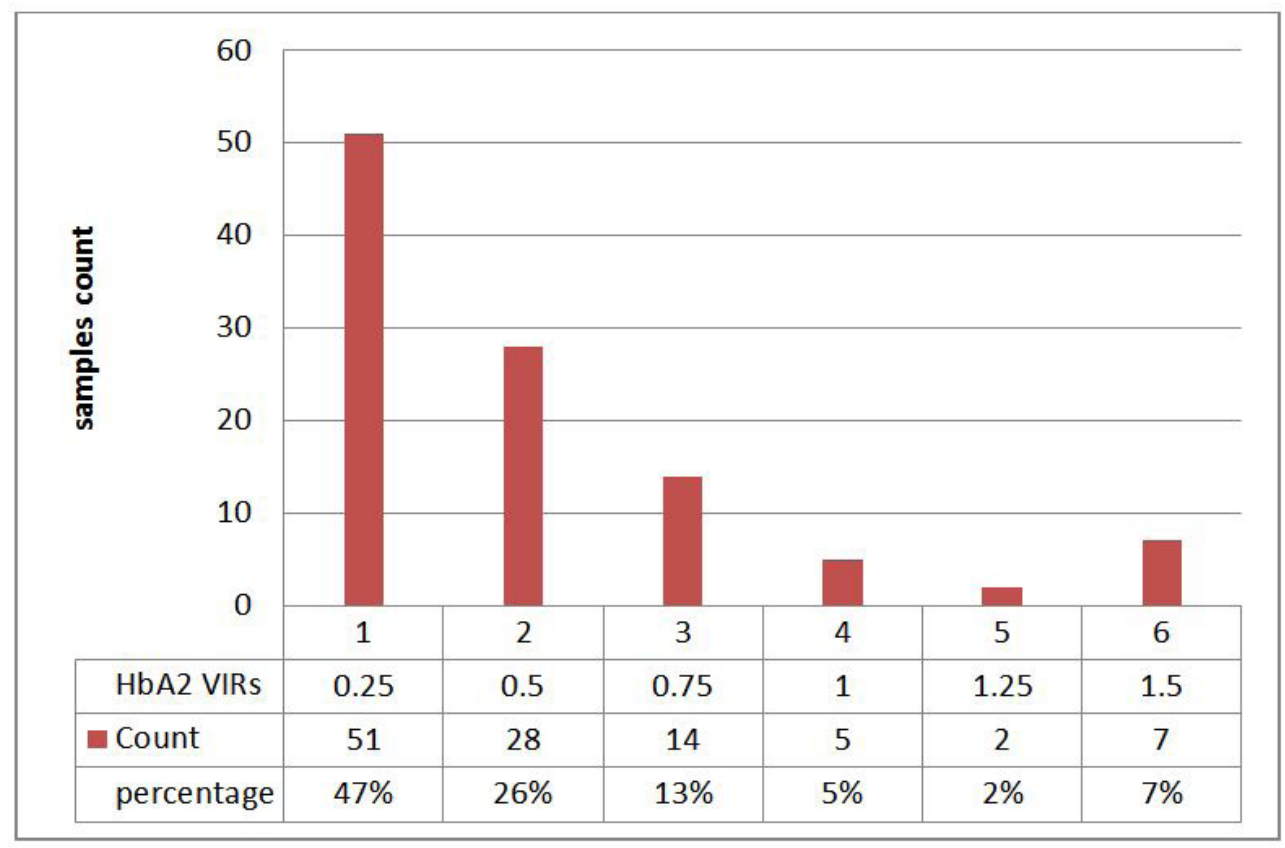

Figure 2: Number of the samples in each variant interval range

For two patients, the first HPLC results showed normal $\mathrm{Hb} \mathrm{A}_{2}$, which was in contradiction with the other parameters. However, when the test was repeated, the $\mathrm{Hb} \mathrm{A}$ became higher than normal, which was consistent with $\beta$-thalassemia trait (Table 2). These results highlight the importance of correlating the $\mathrm{Hb} \mathrm{A}_{2}$ level with other parameters before assigning a final diagnosis. The VIRs for $\mathrm{Hb} \mathrm{A}_{2}$ levels were compared with $\mathrm{RBC}$ indices after sorting the samples based on age and gender, which confirmed the correlation between $\mathrm{Hb} \mathrm{A}_{2}$ levels and RBC indices (Table 3).

Serum ferritin was available in our records for 76 patients but it was not done at the same time as HPLC. As expected, serum ferritin level was within the normal reference range in 63 patients. The serum ferritin level was high $(520-824 \mu \mathrm{g} / \mathrm{L})$ in only 2 patients. Depletion of iron stores was found in 11 patients, Four of these patients were males, with serum ferritin ranged between 10.8 and $17.1 \mu \mathrm{g} / \mathrm{L}$; and 7 were females with a serum ferritin between 3.5 and $10.6 \mu \mathrm{g} / \mathrm{L}$. Interestingly, all patients with low serum ferritin levels, had higher than normal $\mathrm{Hb} \mathrm{A}_{2}$ levels when the HPLC was repeated, and the $\mathrm{Hb} \mathrm{A}_{2}$ stayed greater than normal. Therefore, the diagnosis of $\beta$-thalassemia trait was not altered. This study showed no effect to the low serum ferritin level on $\mathrm{Hb}$ $\mathrm{A}_{2}$ level because with low serum ferritin the RBC count usually drop below the normal range, but the RBC count was high, in consistent to $\beta$-thalassemia trait rather than iron deficiency anemia. It is important finding although 11 samples with low serum ferritin and high $\mathrm{Hb} \mathrm{A}$ and high RBC count is not large enough number to make conclusion about iron deficiency and its effect on the $\mathrm{HbA}_{2}$ level a further study needed for this significant results. This is an important finding because some other studies showed that low serum ferritin was thought to reduce $\mathrm{Hb} \mathrm{A}_{2}$ level to normal or below normal in patients with $\beta$-thalassemia trait $[8,9]$. Serum ferritin level in patients with the $\beta$-thalassemia trait could be high [10]; our results revealed 2 patients with elevated serum ferritin levels without receiving blood transfusion. It is important to be aware of any interference that may falsely alter $\mathrm{Hb}$ $\mathrm{A}_{2}$ levels, leading to false positive (high) or false negative (low) $\mathrm{Hb} \mathrm{A}_{2}$ level result, which may result in inappropriate diagnosis or management [11]. For example, as reported in the literature false negative $\mathrm{Hb} \mathrm{A}_{2}$ could be caused by an iron deficiency or concurrent inheritance of the $\alpha$-thalassemia trait [6]. Therefore, the quantification of $\mathrm{Hb} \mathrm{A}_{2}$ levels has to be with high accuracy [12]. Many factors such as the lack of awareness among working technologists and clinical pathologists, or inadequate facilities, may result in imprecise outcomes and interpretations [13]. Another important finding in this study is that the repeated $\mathrm{Hb}_{2}$ test results of 7 patients (7\%) showed a difference of $1.5 \%$ from their first test results, whereas $\mathrm{Hb} \mathrm{A}_{2}$ variation is only, up to $0.5 \%$ has been reported in literature [14]. This relatively large difference between the initial and repeated results of $\mathrm{Hb} \mathrm{A}_{2}$ levels which may affect result in the interpretation, if the diagnosis is made solely based on HPLC results only. Equipment calibration, regular maintenance, test validation and the laboratory quality control are necessary to ensure high and accurate performance. Equivocal borderline high $\mathrm{Hb} \mathrm{A}_{2}$ results warrant repeat testing using other modalities and/or genetic tests of the globin genes. There are a few cases of symptomatic refractory microcytic hypochromic anemia with borderline, normal, or reduced Hb $\mathrm{A}_{2}$ levels. These cases should be investigated for the presence of $\alpha$-thalassemia or its co-inheritance with $\beta$-thalassemia gene [15], or silent $\beta$-thalassemia trait [16]. This study need to be repeated as a prospective study to confirm the findings with molecular biology techniques which couldn't be done in this retrospective study. 


\section{Conclusion}

The normal range for $\mathrm{Hb} \mathrm{A}_{2}$ is very narrow. Small changes in $\mathrm{Hb} \mathrm{A}_{2}$ levels can result in incorrect diagnosis. In this study the low serum ferritin did not decrease the $\mathrm{Hb} \mathrm{A}_{2}$ to a normal level. Proper machine maintenance, standardized reagents, adequate training of HPLC testing for technologists and interpretive aspects from pathologists and physicians are crucial to make accurate diagnosis. HPLC result interpretation must be done in correlation with family study, RBC parameters, serum ferritin levels, and blood film morphology. High degree of suspicion helps to identify possible false positive or false negative results. Equivocal or inconclusive $\mathrm{Hb} \mathrm{A}_{2}$ results should be investigated further by other methods such as DNA analysis.

\section{Acknowledgement}

We are grateful for the hematology laboratory team in hematology clinical laboratories in Amiri hospital for their assistant in this research work.

\section{References}

1. Ou Z, Li Q, Liu W, Sun X (2011) Elevated hemoglobin A2 as a marker for $\beta$-thalassemia trait in pregnant women. Tohoku J Exp Med 223: 223-6.

2. Galanello R, Origa R (2010) Beta-thalassemia. Orphanet J Rare Dis 21: 11.

3. Weatherall DJ, Clegg JB (2001) The Thalassaemia Syndromes (4 ${ }^{\text {th }}$ Edn) Blackwell Science Publishers, UK.

4. Verma S, Gupta R, Kudesia M, Mathur A, Krishan G, et al. (2014) Coexisting Iron Deficiency Anemia and Beta Thalassemia Trait: Effect of Iron Therapy on Red Cell Parameters and Hemoglobin Subtypes. ISRN Hematol doi: 10.1155/2014/293216.

5. Giordano PC (2003) The effect of iron deficiency anaemia on the levels of haemoglobin subtypes: possible consequences for clinical diagnosis. Clin Lab Haematol 25: 203.

6. Denic S, Agarwal MM, Al Dabbagh B, El Essa A, Takala M, et al. (2013) Hemoglobin A2 Lowered by Iron Deficiency and $\alpha$-Thalassemia: Should Screening Recommendation for $\beta$-Thalassemia Change? ISRN Hematol doi:10.1155/2013/858294.

7. Mosca A, Paleari R, Ivaldi G, Galanello R, Giordano PC (2009) The role of haemoglobin A2 testing in the diagnosis of thalassaemias and related haemoglobinopathies. J Clin Patho 62: 13-7.

8. Hosein PJ, Craig MD, Tallman MS, Boccia RV, Hamilton BL, et al. (2012) A multicenter phase II study of darinaparsin in relapsed or refractory Hodgkin's and non-Hodgkin's lymphoma. Am J Hematol 87: 111-4.

9. Estevão IF, Peitl Junior P, Bonini-Domingos CR (2011) Serum ferritin and transferrin saturation levels in $\beta^{0}$ and $\beta(+)$ thalassemia patients. Genet Mol Res 10: 632-9.

10. Piperno A, Mariani R, Arosio C, Vergani A, Bosio S, et al. (2000) Haemochromatosis in patients with beta-thalassaemia trait. Br J Haematol 111: 908-14.

11. El-Agouza I, Abu Shahla A, Sirdah M (2002) The effect of iron deficiency anaemia on the levels of haemoglobin subtypes: possible consequences for clinical diagnosis. Clin Lab Haematol 24: 285-9.

12. Adeyemo T, Ojewunmi O, Oyetunji A (2014) Evaluation of high performance liquid chromatography (HPLC) pattern and prevalence of beta-thalassaemia trait among sickle cell disease patients in Lagos, Nigeria. Pan Afr Med J 18: 71.

13. Usman M, Moinuddin M, Ahmed SA (2011) Role of iron deficiency anemia in the propagation of beta thalssemia gene. Korean J Hematol 46: 41-4.

14. Higgins TN, Khajuria A, Mack M (2009) Quantification of $\mathrm{HbA}(2)$ in patients with and without beta-thalassemia and in the presence of $\mathrm{HbS}$, $\mathrm{HbC}, \mathrm{HbE}$, and HbD Punjab hemoglobin variants: comparison of two systems. Am J Clin Pathol 131: 357-62.

15. Nadkarni A, Phanasgaonkar S, Colah R, Mohanty D, Ghosh K (2008) Prevalence and molecular characterization of alpha-thalassemia syndromes among Indians. Genet Test 12: 177-80.

16. Mirbehbahani NB, Rashidbaghan A, Mazji M, Behnampour N (2013) National Approach to Premarital Diagnosis of Trait Thalassemia and Silent Carriers. Int J Clini Med 4: 91-5.

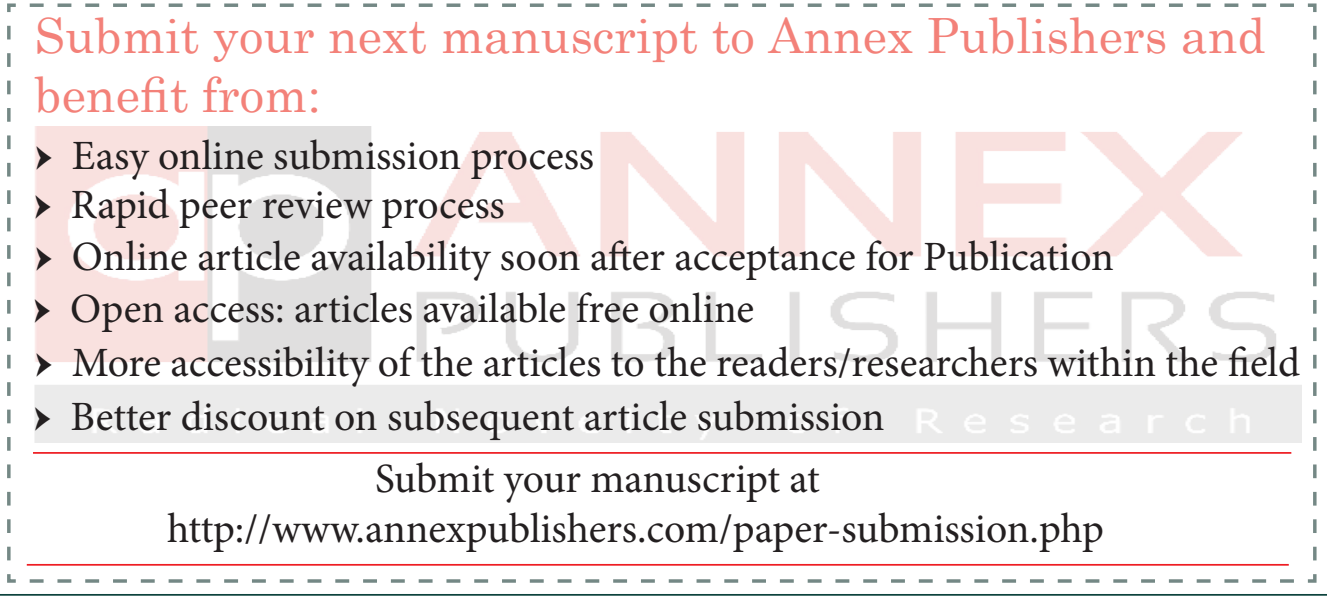

